\title{
Population Genetics in Malaysia and Japanese Populations Using Power Plex Y23 System
}

\author{
Yasutaka Nakamura $^{1)}$, Michinaga Samejima ${ }^{2)}$, Kiyoshi Minaguchi ${ }^{3)}$, \\ Phrabhakaran Nambiar $^{4)}$ and Masatsugu Hashimoto ${ }^{1)}$ \\ 1) Department of Forensic Odontology and Forensic Anthropology, Tokyo Dental College, \\ 2-9-18 Kanda-Misakicho, Chiyoda-ku, Tokyo 101-0061, Japan \\ 2) Private Practice, \\ 1-9-18 Shizunai Kosei-cho, Shinhidaka-cho, Hidaka-gun, Hokkaido, Japan \\ ${ }^{3)}$ Department of Forensic Medicine, Tokai University School of Medicine, \\ 143 Shimokasuya, 15 Isehara-shi, Kanagawa 259-1193, Japan \\ ${ }^{4)}$ Department of Oral Biology, Faculty of Dentistry, University of Malaya, \\ 50603 Kuala Lumpur, Malaysia
}

Received 9 April, 2019/Accepted for Publication 18 April, 2019

Published Online in J-STAGE 10 June, 2020

\begin{abstract}
Population flow between Southeast Asian countries and Japan continues to gather pace. Accordingly, the number of foreigners involved in incidents in Japan has markedly increased, which means that forensic dentistry is now increasingly being faced with the need to analyze DNA from persons of non-Japanese extraction. The DNA test currently used for personal identification mainly utilizes short tandem repeats (STRs) on autosomal chromosomes and the Y-chromosome. This test was developed for use in personal identification, not for distinguishing among races; nonetheless, the standard method for personal identification is often used because the procedure has been established. To determine the degree to which racial differences can be distinguished by standard DNA analysis, 23 STRs located on the Y chromosome were investigated in 218 Malay and 426 Japanese males. The frequencies of each STR were calculated in the two populations. The difference in the power of discrimination between the Malay and Japanese populations ranged from a minimum of 0.01 to a maximum of 0.27 ; the difference in polymorphic information content ranged from 0.01 (minimum) to 0.23 (maximum). No major differences were noted in the polymorphisms in these two Mongoloid populations, but the distributions of the 17 STRs differed significantly. Short tandem repeat types demonstrating a likelihood of racial differences were identified in 14 of the STRs. Race-specific STR types were identified in 10 STRs. These results suggest that the likelihood of Malay or Japanese genetic background can be judged based on Y-chromosome STR test results.
\end{abstract}

Key words: DNA identification - Y-chromosome - STR — Malaysia -

Race determination 


\section{Introduction}

The 'Out of Africa' theory of the origin of the human race is widely held. According to this theory, one part of this population then left Africa, traversing the Arabian Peninsula to reach the Malay Peninsula via the Indian Peninsula, after which it further diffused into Indonesia. From there, as one population crossed the ocean to reach Japan, another migrated northward along the south margin of Eurasia, diffusing throughout Northeast Asia and eventually migrating southward to reach Japan. Given that this migration path originated in Africa, the Southeast Asian region has been demonstrated to have played an important role in interchange with Mongoloid peoples based on MtDNA and Y-chromosome haplogroups $s^{1,2,6,7,10)}$.

At present, Malaysia is made up of approximately $65 \%$ Malay, $24 \%$ ethnic Chinese, and $8 \%$ Indian populations. Malay people are widely distributed throughout Southeast Asia, including Indonesia, Brunei, Thailand, and Singapore. An earlier study by this group used autosomal chromosomal short tandem repeats (STRs) to investigate the racial breakdown of the Malaysian population ${ }^{4)}$. In the present study, polymorphism information on 23 STRs on the Y chromosome was acquired from 218 male Malaysians living near Kuala Lumpur in Malaysia and compared with similarly acquired population data for 426 Japanese males. The Y-STR test tool used was PowerPlex ${ }^{\circledR}$ Y23 (Promega, USA). This DNA test is not exclusively designed for purposes of racial differentiation; rather, it is typically used as the first choice for blood relation analysis and personal identification by the police and in the field of forensics ${ }^{9)}$. The purpose of the present study was to determine the possibility of estimating race based on a standard DNA test that was not developed for the purpose of distinguishing racial background. Specifically, the efficacy of PowerPlex $^{\circledR}$ was investigated in distinguishing Japanese and Malay populations.

\section{Materials and Methods}

\section{Samples}

Malay genomic DNA was extracted from tooth samples obtained from 218 unrelated Malay men living in or around Kuala Lumpur. Appropriate consent was obtained from the patients. Within the Malay Archipelago, the population distribution is $65 \%$ Malaysian, 24\% Chinese, and 8\% Indian. This study used data exclusively of Malay archipelago origin. A family history also was taken to ensure that the parents of these participants were of Malay origin. No tribal population samples were included in the study. Japanese genomic DNA was extracted from blood samples obtained from 426 unrelated Japanese men. Informed consent was obtained from all donors, including those individuals in the case samples.

The protocol of this study was approved by the Ethics Committee of Tokyo Dental College (approval no.202 and 204) and met the conditions for cooperative study at the University of Malaya.

\section{DNA extraction}

Isolation of genomic DNA from tooth and blood samples was performed as described previously ${ }^{3}$. Permanent teeth extracted during dental treatment were used to obtain each sample. Each tooth was crushed to facilitate extraction of DNA.

\section{PCR}

PCR amplification and typing of Y-chromosome STRs targeted the following loci: DYS576, DYS389I, DYS389II, DYS448, DYS19, DYS391, DYS481, DYS549, DYS533, DYS438, DYS437, DYS570, DYS635, DYS390, DYS439, DYS392, DYS643, DYS393, DYS458, DYS385a, DYS385b, DYS456, and GATA-H4. Typing was performed using the Investigator PowerPlex ${ }^{\circledR}$ Y23 System PCR Amplification kit (Promega).

Table 1 shows the positional information for each STR. The sequences of the primers used in this kit were not disclosed by the manufacturer. 
Table 1 Physical location of 23 Y-STRs

\begin{tabular}{cc}
\hline \hline Locus & $\begin{array}{c}\text { Physical } \\
\text { location (bp) }\end{array}$ \\
\hline DYS 393 & $3,131,128$ \\
DYS 456 & $4,270,942$ \\
DYS 570 & $6,861,115$ \\
DYS 576 & $7,053,302$ \\
DYS 458 & $7,867,839$ \\
DYS 481 & $8,426,350$ \\
DYS 19 & $9,521,935$ \\
DYS 391 & $14,102,769$ \\
DYS 635 & $14,379,486$ \\
DYS 437 & $14,466,964$ \\
DYS 439 & $14,515,188$ \\
DYS 389 I & $14,612,164$ \\
DYS 389 II & $14,612,164$ \\
DYS 438 & $14,937,785$ \\
DYS 390 & $17,274,885$ \\
DYS 643 & $17,425,969$ \\
DYS 533 & $18,393,105$ \\
GATA-H4 & $18,743,528$ \\
DYS 385a & $20,801,569$ \\
DYS 385b & $20,842,336$ \\
DYS 549 & $21,520,190$ \\
DYS 392 & $22,633,848$ \\
DYS 448 & $24,364,964$ \\
\hline
\end{tabular}

An ABI PRIZM 3130 Genetic Analyzer (Applied Biosystems, USA) was used to perform electrophoresis under the conditions described in the manufacturer's recommendations. Fragment sizes were determined automatically using GeneScan Analysis software 3.1 (Applied Biosystems) and the results analyzed using Genotyper version 2.5 (Applied Biosystems).

\section{Statistical analysis}

The Matching Probability (MP), the power of discrimination (PD), and the polymorphic information content (PIC) were calculated using PowerStatsV12 software (http://www. promega.com $)^{8}$. The $p$-values were determined using the Fisher's exact test from
GENEPOP software version 4.2 (http:/ / genepop.curtin.edu.au $)^{5)}$.

\section{Results}

Tables 2a-w show the allele frequencies of the 23 STR loci evaluated in the Malay and Japanese populations. The PD and PIC are indices of polymorphism, and the MP is the probability of coincidence. The difference in PD between the two populations ranged from a maximum of 0.27 to a minimum of 0.01 , while that in PIC ranged from 0.23 to 0.01 . In general, the number of polymorphisms was higher in the Malay population than in the Japanese population. As both populations are Mongoloid and of the same origin, there was no major difference between the two populations. To clarify detailed differences, any STR type with an allele frequency of less than $1 \%$ was considered to be a mutation and excluded. The allele frequency distributions in the two populations were subjected to Fisher's exact analysis. The p-values of the 6 STRs (DYS549, DYS570, DYS437, DYS19, DYS389II, and DYS392) were highly similar among the two populations, with a p-value of 0.05 or higher. A significant difference was noted for 17 STRs (p-value $<0.01$ ). A total of 8 STRs (DYS385a, DYS389I, DYS438, DYS481, DYS390, DYS533, DYS439, and DYS643) were considered the most useful for racial differentiation (Table 3). The smallest difference was noted in the allele frequency of DYS549. The distribution of this type is shown in Fig. 1. In DYS549, the allele frequency of type 12 was the highest in both populations. The distribution was unimodal, and types with many repeats (right side of the graph) were dominant, with type 12 representing the most frequent allele. The absence of any difference between the 2 populations suggests that this STR has been present for a long time without change, and may be characteristic of Mongoloids. Its usefulness for racial differentiation is low. In DYS385a, type 13 exhibited the maximum allele frequency in both populations, but the overall distribution was bimodal, with type 
Table 2a Observed allele frequencies for DYS19 loci in Malay and Japanese

\begin{tabular}{ccc}
\hline \multirow{2}{*}{ Locus } & \multicolumn{2}{c}{ DYS19 } \\
\cline { 2 - 3 } & Malay & Japan \\
\hline Total Alleles & 218 & 426 \\
\hline Allele & \multicolumn{2}{c}{ Frequency } \\
\hline 12 & $1.8 \%$ & $0.0 \%$ \\
13 & $3.7 \%$ & $4.2 \%$ \\
14 & $17.0 \%$ & $8.0 \%$ \\
15 & $50.0 \%$ & $45.1 \%$ \\
16 & $17.9 \%$ & $22.1 \%$ \\
17 & $8.7 \%$ & $20.4 \%$ \\
18 & $0.9 \%$ & $0.2 \%$ \\
\hline p-Value & 0.0866405 \\
\hline MP & 0.320 & 0.302 \\
PD & 0.680 & 0.698 \\
PIC & 0.64 & 0.65 \\
\hline
\end{tabular}

p-Value: Probability value from Fisher's exact test.

MP: Matching Probability.

PD: Power of Discrimination.

PIC: Polymorphism Information content.
Table 2b Observed allele frequencies for DYS385a loci in Malay and Japanese

\begin{tabular}{ccc}
\hline \hline \multirow{2}{*}{ Locus } & \multicolumn{2}{c}{ DYS385a } \\
\cline { 2 - 3 } & Malay & Japan \\
\hline Total Alleles & 218 & 426 \\
\hline Allele & \multicolumn{2}{c}{ Frequency } \\
\hline 6 & $0.5 \%$ & $0.0 \%$ \\
7 & $0.0 \%$ & $0.0 \%$ \\
8 & $0.0 \%$ & $0.0 \%$ \\
9 & $0.5 \%$ & $1.2 \%$ \\
10 & $2.8 \%$ & $30.0 \%$ \\
11 & $17.0 \%$ & $5.9 \%$ \\
12 & $19.7 \%$ & $13.4 \%$ \\
13 & $22.5 \%$ & $30.3 \%$ \\
13.2 & $0.0 \%$ & $0.2 \%$ \\
14 & $10.1 \%$ & $12.7 \%$ \\
15 & $18.3 \%$ & $4.5 \%$ \\
16 & $6.0 \%$ & $1.4 \%$ \\
17 & $1.4 \%$ & $0.2 \%$ \\
18 & $0.9 \%$ & $0.2 \%$ \\
19 & $0.5 \%$ & $0.0 \%$ \\
\hline p-Value & $6.18057 \mathrm{E}-07$ \\
\hline MP & 0.167 & 0.222 \\
PD & 0.833 & 0.778 \\
PIC & 0.81 & 0.75 \\
\hline & & \\
\hline
\end{tabular}

Abbreviation: shown in Table 2a
Table 2c Observed allele frequencies for DYS385b loci in Malay and Japanese

\begin{tabular}{|c|c|c|}
\hline \multirow{2}{*}{ Locus } & \multicolumn{2}{|c|}{ DYS385b } \\
\hline & Malay & Japan \\
\hline $\begin{array}{c}\text { Total } \\
\text { Alleles }\end{array}$ & 218 & 426 \\
\hline Allele & \multicolumn{2}{|c|}{ Frequency } \\
\hline 11 & $0.9 \%$ & $0.0 \%$ \\
\hline 12 & $2.8 \%$ & $2.6 \%$ \\
\hline 13 & $4.1 \%$ & $3.3 \%$ \\
\hline 14 & $21.6 \%$ & $3.5 \%$ \\
\hline 15 & $10.6 \%$ & $4.0 \%$ \\
\hline 16 & $10.1 \%$ & $6.3 \%$ \\
\hline 17 & $9.6 \%$ & $25.6 \%$ \\
\hline 18 & $13.3 \%$ & $20.0 \%$ \\
\hline 19 & $13.3 \%$ & $16.4 \%$ \\
\hline 19.2 & $0.5 \%$ & $0.0 \%$ \\
\hline 20 & $8.7 \%$ & $12.7 \%$ \\
\hline 21 & $3.2 \%$ & $3.8 \%$ \\
\hline 22 & $1.4 \%$ & $0.7 \%$ \\
\hline 23 & $0.0 \%$ & $0.5 \%$ \\
\hline 24 & $0.0 \%$ & $0.2 \%$ \\
\hline 25 & $0.0 \%$ & $0.2 \%$ \\
\hline 27 & $0.0 \%$ & $0.2 \%$ \\
\hline p-Value & \multicolumn{2}{|c|}{0.0052308} \\
\hline MP & 0.124 & 0.158 \\
\hline PD & 0.876 & 0.842 \\
\hline PIC & 0.86 & 0.82 \\
\hline
\end{tabular}

Abbreviation: shown in Table 2a

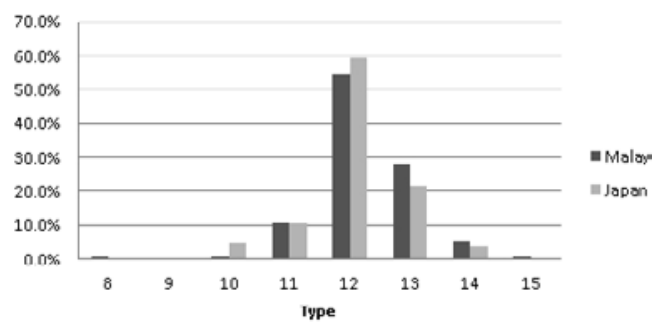

Fig. 1 Frequency distribution of DYS549 Frequency distribution of DYS549 in Malay and Japanese populations.

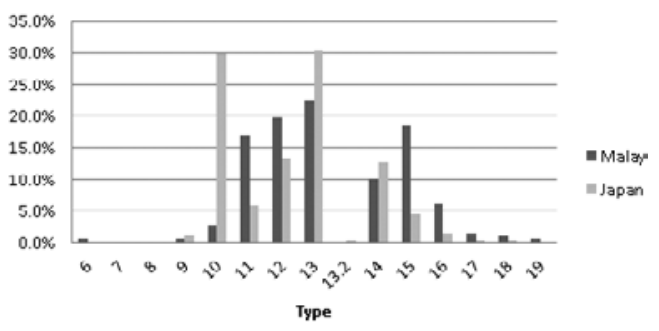

Fig. 2 Frequency distribution of DYS385a Frequency distribution of DYS385a in Malay and Japanese populations. 
Table 2d Observed allele frequencies for DYS391 loci in Malay and Japanese

\begin{tabular}{ccc}
\hline \multirow{2}{*}{ Locus } & \multicolumn{2}{c}{ DYS391 } \\
\cline { 2 - 3 } & Malay & Japan \\
\hline Total Alleles & 218 & 426 \\
\hline Allele & \multicolumn{2}{c}{ Frequency } \\
\hline 8 & $0.0 \%$ & $0.2 \%$ \\
9 & $11.9 \%$ & $1.4 \%$ \\
10 & $68.3 \%$ & $88.0 \%$ \\
11 & $18.8 \%$ & $9.6 \%$ \\
12 & $0.9 \%$ & $0.7 \%$ \\
\hline p-Value & 0.00212661 \\
\hline MP & 0.517 & 0.784 \\
PD & 0.483 & 0.216 \\
PIC & 0.44 & 0.20 \\
\hline
\end{tabular}

Abbreviation: shown in Table 2a
Table 2e Observed allele frequencies for DYS549 loci in Malay and Japanese

\begin{tabular}{ccc}
\hline \multirow{2}{*}{ Locus } & \multicolumn{2}{c}{ DYS549 } \\
\cline { 2 - 3 } & Malay & Japan \\
\hline Total Alleles & 218 & 426 \\
\hline Allele & \multicolumn{2}{c}{ Frequency } \\
\hline 8 & $0.5 \%$ & $0.0 \%$ \\
9 & $0.0 \%$ & $0.0 \%$ \\
10 & $0.5 \%$ & $4.7 \%$ \\
11 & $11.0 \%$ & $10.6 \%$ \\
12 & $54.6 \%$ & $59.4 \%$ \\
13 & $28.0 \%$ & $21.6 \%$ \\
14 & $5.0 \%$ & $3.8 \%$ \\
15 & $0.5 \%$ & $0.0 \%$ \\
\hline p-Value & 0.202757 \\
\hline MP & 0.391 & 0.414 \\
PD & 0.609 & 0.586 \\
PIC & 0.55 & 0.54 \\
\hline
\end{tabular}

Abbreviation: shown in Table 2a
Table 2f Observed allele frequencies for DYS392 loci in Malay and Japanese

\begin{tabular}{ccc}
\hline \multirow{2}{*}{ Locus } & \multicolumn{2}{c}{ DYS392 } \\
\cline { 2 - 3 } & Malay & Japan \\
\hline Total Alleles & 218 & 426 \\
\hline Allele & \multicolumn{2}{c}{ Frequency } \\
\hline 10 & $2.8 \%$ & $0.5 \%$ \\
11 & $33.9 \%$ & $42.0 \%$ \\
12 & $12.8 \%$ & $7.3 \%$ \\
13 & $28.0 \%$ & $38.7 \%$ \\
14 & $18.8 \%$ & $10.1 \%$ \\
15 & $2.8 \%$ & $0.7 \%$ \\
16 & $0.9 \%$ & $0.5 \%$ \\
17 & $0.0 \%$ & $0.2 \%$ \\
\hline p-Value & 0.0571873 \\
\hline MP & 0.247 & 0.342 \\
PD & 0.753 & 0.658 \\
PIC & 0.71 & 0.59 \\
\hline
\end{tabular}

Abbreviation: shown in Table 2a

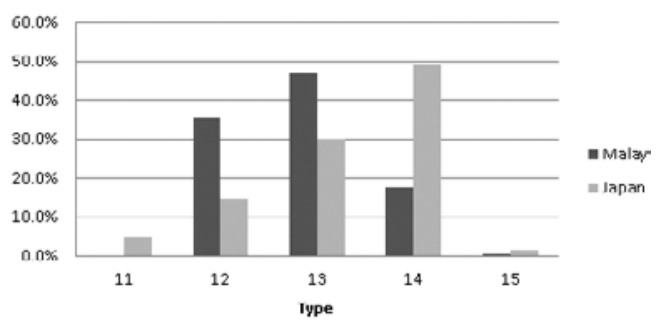

Fig. 3 Frequency distribution of DYS389 I

Frequency distribution of DYS389 I in Malay and Japanese populations.

13.2 as a boundary, and there were clear differences in the allele frequency between the two populations. Types 10 or lower were dominant in Japanese, whereas types 15 or higher were dominant in Malay (Fig. 2). In DYS389I, the maximum allele frequency was noted in type 13 in Malay and type 14 in Japanese. The distribution was concentrated in types 12 and 13 in Malay, whereas types 11 or

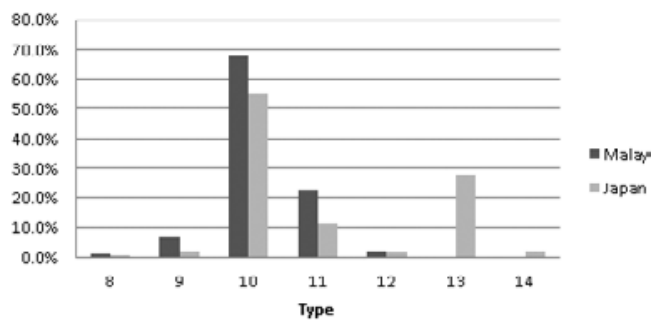

Fig. 4 Frequency distribution of DYS438

Frequency distribution of DYS438 in Malay and Japanese populations.

lower and 14 or higher were dominant in Japanese (Fig. 3). In DYS438, the maximum allele frequency was noted in type 10 in both populations, and the overall distribution was bimodal, with type 12 as a boundary. Types 11 or lower were dominant in Malay, whereas types 13 or higher were dominant in Japanese (Fig. 4). In DYS481, the maximum allele frequency was noted in type 23 in Malay, and 
Table $2 \mathrm{~g}$ Observed allele frequencies for DYS643 loci in Malay and Japanese

\begin{tabular}{ccc}
\hline \hline \multirow{2}{*}{ Locus } & \multicolumn{2}{c}{ DYS643 } \\
\cline { 2 - 3 } & Malay & Japan \\
\hline Total Alleles & 218 & 426 \\
\hline Allele & \multicolumn{2}{c}{ Frequency } \\
\hline 7 & $1.8 \%$ & $0.0 \%$ \\
8 & $0.0 \%$ & $1.2 \%$ \\
9 & $11.5 \%$ & $3.1 \%$ \\
10 & $14.2 \%$ & $8.5 \%$ \\
11 & $34.4 \%$ & $22.3 \%$ \\
11.1 & $2.3 \%$ & $0.0 \%$ \\
12 & $32.1 \%$ & $50.0 \%$ \\
13 & $3.2 \%$ & $11.5 \%$ \\
14 & $0.0 \%$ & $3.3 \%$ \\
15 & $0.5 \%$ & $0.2 \%$ \\
\hline p-Value & 0.000999386 \\
\hline MP & 0.257 & 0.322 \\
PD & 0.743 & 0.678 \\
PIC & 0.70 & 0.64 \\
\hline
\end{tabular}

Abbreviation: shown in Table 2a
Table $2 \mathrm{~h}$ Observed allele frequencies for DYS393 loci in Malay and Japanese

\begin{tabular}{ccc}
\hline \hline \multirow{2}{*}{ Locus } & \multicolumn{2}{c}{ DYS393 } \\
\cline { 2 - 3 } & Malay & Japan \\
\hline Total Alleles & 218 & 426 \\
\hline Allele & \multicolumn{2}{c}{ Frequency } \\
\hline 11 & $0.9 \%$ & $1.4 \%$ \\
12 & $20.6 \%$ & $20.0 \%$ \\
13 & $43.6 \%$ & $64.1 \%$ \\
14 & $29.8 \%$ & $11.7 \%$ \\
15 & $5.0 \%$ & $2.6 \%$ \\
16 & $0.0 \%$ & $0.2 \%$ \\
\hline p-Value & 0.0178206 \\
\hline MP & 0.324 & 0.465 \\
PD & 0.676 & 0.535 \\
PIC & 0.62 & 0.49 \\
\hline
\end{tabular}

Abbreviation: shown in Table $2 \mathrm{a}$
Table 2i Observed allele frequencies for DYS456 loci in Malay and Japanese

\begin{tabular}{ccc}
\hline \multirow{2}{*}{ Locus } & \multicolumn{2}{c}{ DYS456 } \\
\cline { 2 - 3 } & Malay & Japan \\
\hline Total Alleles & 218 & 425 \\
\hline Allele & \multicolumn{2}{c}{ Frequency } \\
\hline 12 & $0.0 \%$ & $0.5 \%$ \\
13 & $1.4 \%$ & $0.7 \%$ \\
14 & $9.6 \%$ & $4.9 \%$ \\
15 & $50.0 \%$ & $69.6 \%$ \\
16 & $24.3 \%$ & $20.5 \%$ \\
17 & $11.9 \%$ & $3.3 \%$ \\
18 & $2.8 \%$ & $0.5 \%$ \\
\hline p-Value & 0.0172153 \\
\hline MP & 0.334 & 0.531 \\
PD & 0.666 & 0.469 \\
PIC & 0.62 & 0.42 \\
\hline
\end{tabular}

Abbreviation: shown in Table 2a

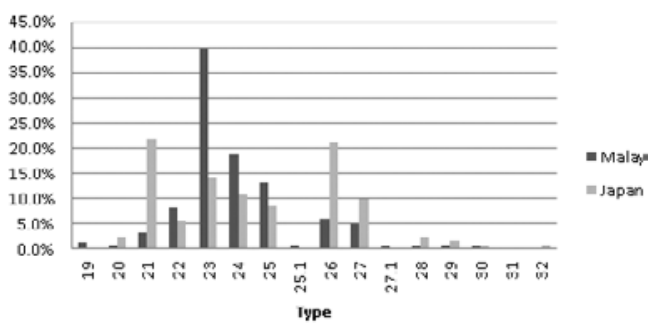

Fig. 5 Frequency distribution of DYS481

Frequency distribution of DYS481 in Malay and Japanese populations.

types 21 and 26 in Japanese. The distribution was concentrated in types 22-25 in Malay, whereas types 21 or lower and 26 or higher were dominant in Japanese (Fig. 5). In DYS390, types 22-25 accounted for more than $80 \%$ in both populations, but types 21 or lower were noted only in Malay (Fig. 6). In

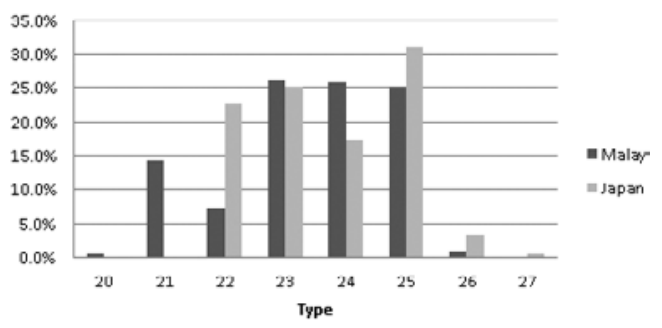

Fig. 6 Frequency distribution of DYS390

Frequency distribution of DYS390 in Malay and Japanese populations.

DYS533, the maximum allele frequency was noted in type 11 in both populations, and types 10 or lower were dominant in Malay, whereas types 12 or higher were dominant in Japanese (Fig. 7). In DYS439, the maximum allele frequency was noted in type 12 in both populations, and types 11 or lower were domi- 
Table 2j Observed allele frequencies for DYS438 loci in Malay and Japanese

\begin{tabular}{ccc}
\hline \hline \multirow{2}{*}{ Locus } & \multicolumn{2}{c}{ DYS438 } \\
\cline { 2 - 3 } & Malay & Japan \\
\hline Total Alleles & 218 & 426 \\
\hline Allele & \multicolumn{2}{c}{ Frequency } \\
\hline 8 & $0.9 \%$ & $0.2 \%$ \\
9 & $6.9 \%$ & $2.1 \%$ \\
10 & $67.9 \%$ & $55.2 \%$ \\
11 & $22.5 \%$ & $11.5 \%$ \\
12 & $1.8 \%$ & $1.4 \%$ \\
13 & $0.0 \%$ & $27.7 \%$ \\
14 & $0.0 \%$ & $1.9 \%$ \\
\hline p-Value & $9.27129 \mathrm{E}-07$ \\
\hline MP & 0.517 & 0.395 \\
PD & 0.483 & 0.605 \\
PIC & 0.43 & 0.55 \\
\hline
\end{tabular}

Abbreviation: shown in Table 2a

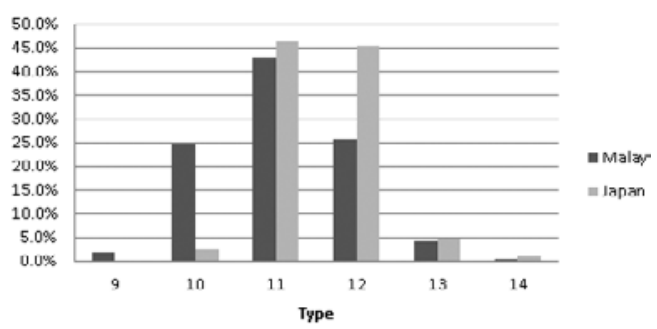

Fig. 7 Frequency distribution of DYS533

Frequency distribution of DYS533 in Malay and Japanese populations.

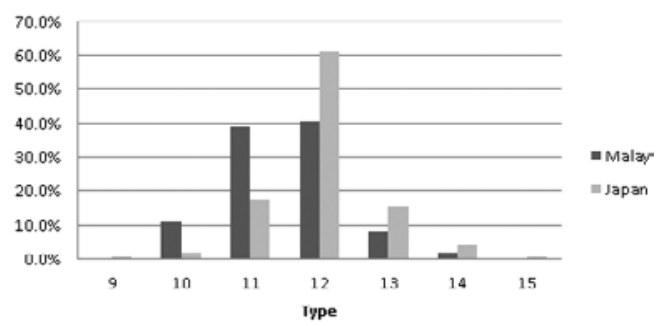

Fig. 8 Frequency distribution of DYS439

Frequency distribution of DYS439 in Malay and Japanese populations.
Table 21 Observed allele frequencies for DYS481 loci in Malay and Japanese

\begin{tabular}{|c|c|c|}
\hline \multirow{2}{*}{ Locus } & \multicolumn{2}{|c|}{ DYS481 } \\
\hline & Malay & Japan \\
\hline Total Alleles & 218 & 426 \\
\hline Allele & \multicolumn{2}{|c|}{ Frequency } \\
\hline 19 & $1.4 \%$ & $0.0 \%$ \\
\hline 20 & $0.9 \%$ & $2.3 \%$ \\
\hline 21 & $3.2 \%$ & $21.8 \%$ \\
\hline 22 & $8.3 \%$ & $5.6 \%$ \\
\hline 23 & $39.9 \%$ & $14.1 \%$ \\
\hline 24 & $18.8 \%$ & $10.8 \%$ \\
\hline 25 & $13.3 \%$ & $8.5 \%$ \\
\hline 25.1 & $0.9 \%$ & $0.0 \%$ \\
\hline 26 & $6.0 \%$ & $21.4 \%$ \\
\hline 27 & $5.0 \%$ & $9.9 \%$ \\
\hline 27.1 & $0.5 \%$ & $0.0 \%$ \\
\hline 28 & $0.5 \%$ & $2.6 \%$ \\
\hline 29 & $0.9 \%$ & $1.6 \%$ \\
\hline 30 & $0.5 \%$ & $0.5 \%$ \\
\hline 31 & $0.0 \%$ & $0.2 \%$ \\
\hline 32 & $0.0 \%$ & $0.7 \%$ \\
\hline $\mathrm{p}$-Value & \multicolumn{2}{|c|}{$4.27111 \mathrm{E}-06$} \\
\hline MP & 0.227 & 0.146 \\
\hline $\mathrm{PD}$ & 0.773 & 0.854 \\
\hline PIC & 0.75 & 0.84 \\
\hline
\end{tabular}

Abbreviation: shown in Table 2a

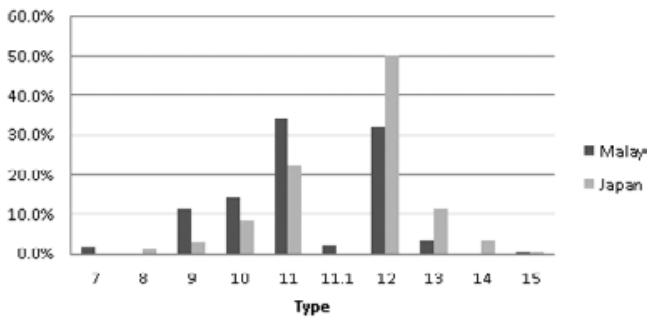

Fig. 9 Frequency distribution of DYS643

Frequency distribution of DYS643 in Malay and Japanese populations. 
Table $2 \mathrm{~m}$ Observed allele frequencies for DYS533 loci in Malay and Japanese

\begin{tabular}{ccc}
\hline \hline \multirow{2}{*}{ Locus } & \multicolumn{2}{c}{ DYS533 } \\
\cline { 2 - 3 } & Malay & Japan \\
\hline Total Alleles & 218 & 426 \\
\hline Allele & \multicolumn{2}{c}{ Frequency } \\
\hline 9 & $1.8 \%$ & $0.0 \%$ \\
10 & $24.8 \%$ & $2.6 \%$ \\
11 & $43.1 \%$ & $46.2 \%$ \\
12 & $25.7 \%$ & $45.3 \%$ \\
13 & $4.1 \%$ & $4.9 \%$ \\
14 & $0.5 \%$ & $0.9 \%$ \\
\hline p-Value & 0.000107509 \\
\hline MP & 0.315 & 0.422 \\
PD & 0.685 & 0.578 \\
PIC & 0.63 & 0.49 \\
\hline
\end{tabular}

Abbreviation: shown in Table 2a
Table 2n Observed allele frequencies for DYS570 loci in Malay and Japanese

\begin{tabular}{ccc}
\hline \hline \multirow{2}{*}{ Locus } & \multicolumn{2}{c}{ DYS570 } \\
\cline { 2 - 3 } & Malay & Japan \\
\hline Total Alleles & 218 & 426 \\
\hline Allele & \multicolumn{2}{c}{ Frequency } \\
\hline 13 & $0.5 \%$ & $0.0 \%$ \\
14 & $3.2 \%$ & $1.2 \%$ \\
15 & $6.0 \%$ & $2.3 \%$ \\
16 & $20.2 \%$ & $10.8 \%$ \\
17 & $15.1 \%$ & $26.3 \%$ \\
18 & $25.2 \%$ & $20.0 \%$ \\
19 & $17.0 \%$ & $20.0 \%$ \\
19.3 & $0.0 \%$ & $0.2 \%$ \\
20 & $8.7 \%$ & $12.9 \%$ \\
21 & $4.1 \%$ & $4.7 \%$ \\
22 & $0.0 \%$ & $1.4 \%$ \\
23 & $0.0 \%$ & $0.2 \%$ \\
\hline p-Value & \multicolumn{2}{c}{0.190552} \\
\hline MP & 0.170 & 0.180 \\
PD & 0.830 & 0.820 \\
PIC & 0.81 & 0.80 \\
\hline
\end{tabular}

Abbreviation: shown in Table 2a
Table 2o Observed allele frequencies for DYS390 loci in Malay and Japanese

\begin{tabular}{ccc}
\hline \multirow{2}{*}{ Locus } & \multicolumn{2}{c}{ DYS390 } \\
\cline { 2 - 3 } & Malay & Japan \\
\hline Total Alleles & 218 & 426 \\
\hline Allele & \multicolumn{2}{c}{ Frequency } \\
\hline 20 & $0.5 \%$ & $0.0 \%$ \\
21 & $14.2 \%$ & $0.0 \%$ \\
22 & $7.3 \%$ & $22.8 \%$ \\
23 & $26.1 \%$ & $25.1 \%$ \\
24 & $25.7 \%$ & $17.4 \%$ \\
25 & $25.2 \%$ & $31.0 \%$ \\
26 & $0.9 \%$ & $3.3 \%$ \\
27 & $0.0 \%$ & $0.5 \%$ \\
\hline p-Value & $8.61223 \mathrm{E}-05$ \\
\hline MP & 0.224 & 0.242 \\
PD & 0.776 & 0.758 \\
PIC & 0.74 & 0.72 \\
\hline
\end{tabular}

Abbreviation: shown in Table $2 \mathrm{a}$ nant in Malay, whereas types 13 or higher were dominant in Japanese (Fig. 8). In DYS643, the maximum allele frequency was noted in type 11 in Malay and type 12 in Japanese. Types 11 or lower were dominant, with type 11.1 as a boundary in Malay, whereas types 12 or higher were dominant in Japanese (Fig. 9).

\section{Discussion}

Since the technique of differentiating race based on Y-chromosome single nucleotide polymorphisms (SNPs) was first demonstrated by Peter Au and others, the study of Y-chromosome haplogroups has gained much attention. The Malay and Japanese popula- tions share the same group (haplogroup O), and have been shown to be closely related. The results of the present study based on STRs support those of these earlier investigations using SNPs. Malay people are considered to be the ancestors of the Jomon people, and comparison with the Japanese population is therefore anthropologically meaningful. Comparison of DNA between Malay and Japanese populations is also significant for forensic dentistry, as the number of foreign travelers and workers visiting Japan from Southeast Asian countries is increasing each year.

The present results revealed dominant distribution zones in each population, suggesting that the two races can be distinguished by evaluating these STRs. Furthermore, type 15 
Table $2 p$ Observed allele frequencies for DYS576 loci in Malay and Japanese

\begin{tabular}{ccc}
\hline \hline \multirow{2}{*}{ Locus } & \multicolumn{2}{c}{ DYS576 } \\
\cline { 2 - 3 } & Malay & Japan \\
\hline Total Alleles & 218 & 426 \\
\hline Allele & \multicolumn{2}{c}{ Frequency } \\
\hline 11 & $0.5 \%$ & $0.0 \%$ \\
13 & $0.5 \%$ & $0.0 \%$ \\
14 & $0.5 \%$ & $0.0 \%$ \\
15 & $8.7 \%$ & $0.9 \%$ \\
16 & $11.0 \%$ & $5.4 \%$ \\
17 & $21.6 \%$ & $13.8 \%$ \\
18 & $30.7 \%$ & $26.8 \%$ \\
19 & $16.5 \%$ & $32.6 \%$ \\
20 & $9.2 \%$ & $15.5 \%$ \\
21 & $0.5 \%$ & $3.8 \%$ \\
22 & $0.5 \%$ & $1.2 \%$ \\
\hline p-Value & 0.00223763 \\
\hline MP & 0.196 & 0.226 \\
PD & 0.804 & 0.774 \\
PIC & 0.78 & 0.74 \\
\hline
\end{tabular}

Abbreviation: shown in Table 2a
Table $2 q$ Observed allele frequencies for DYS448 loci in Malay and Japanese

\begin{tabular}{cc}
\hline \multirow{2}{*}{ Locus } & \multicolumn{2}{c}{ DYS448 } \\
\cline { 2 - 2 } & Malay Japan \\
\hline
\end{tabular}

\begin{tabular}{ccc}
\hline Total Alleles & 218 & 424 \\
\hline Allele & Frequency \\
\hline 15 & $0.5 \%$ & $0.0 \%$
\end{tabular}

\begin{tabular}{rrr}
\hline 15 & $0.5 \%$ & $0.0 \%$ \\
16 & $4.6 \%$ & $2.8 \%$ \\
17 & $11.0 \%$ & $8.5 \%$
\end{tabular}

18

$26.1 \%$

$41.0 \%$

19

$21.6 \%$

$32.1 \%$

20

$26.1 \%$

$11.3 \%$

21

$9.2 \%$

$4.0 \%$

22

$0.9 \%$

$0.2 \%$

\begin{tabular}{cll}
\hline p-Value & \multicolumn{2}{c}{0.0188783} \\
\hline MP & 0.206 & 0.294 \\
PD & 0.794 & 0.706 \\
PIC & 0.76 & 0.66 \\
\hline
\end{tabular}

Abbreviation: shown in Table 2a
Table 2r Observed allele frequencies for DYS635 loci in Malay and Japanese

\begin{tabular}{ccc}
\hline \hline \multirow{2}{*}{ Locus } & \multicolumn{2}{c}{ DYS635 } \\
\cline { 2 - 3 } & Malay & Japan \\
\hline Total Alleles & 218 & 426 \\
\hline Allele & \multicolumn{2}{c}{ Frequency } \\
\hline 18 & $0.9 \%$ & $0.0 \%$ \\
19 & $3.2 \%$ & $2.6 \%$ \\
20 & $14.7 \%$ & $31.7 \%$ \\
21 & $39.9 \%$ & $49.8 \%$ \\
22 & $17.4 \%$ & $9.9 \%$ \\
23 & $15.1 \%$ & $3.8 \%$ \\
24 & $7.3 \%$ & $2.1 \%$ \\
25 & $1.4 \%$ & $0.2 \%$ \\
\hline p-Value & \multicolumn{2}{c}{0.00177995} \\
\hline MP & 0.241 & 0.360 \\
PD & 0.759 & 0.640 \\
PIC & 0.73 & 0.58 \\
\hline Abbreviation: shown in Table $2 \mathrm{a}$
\end{tabular}

or higher of DYS385a is the dominant distribution zone in Malay. Focusing on type 15 alone, the allele frequency was $18.3 \%$ in Malay and $4.5 \%$ in Japanese. This represents a 4 -fold difference in the allele frequency. Thus, a person with type 15 is more likely to be Malay than Japanese. As type 15 of DYS385a is common in Malay but rare in Japanese, a person with this type can be presumed to be Malay. On the other hand, type 10 or lower is the dominant distribution zone in Japanese. The allele frequency of type 10 was $30 \%$ in Japanese and $2.8 \%$ in Malay. This represents a 10 -fold difference in the allele frequency. Based on this difference in allele frequency, type 10 of DYS385a may be seen as common in Japanese but rare in Malay. Therefore, a person with this type can be presumed to be Japanese. It is difficult to judge a person as
Japanese based on this type alone. There are several types of STR demonstrating the likelihood of a specific race, however, such as type 10 of DYS385a. When several such types are present, the two races can be distinguished with a high degree of accuracy. Therefore, we defined a type with an allele frequency in Malay that was 4-fold or higher compared to the frequency in Japanese. The presence of an allele that is known to have a frequency of $5 \%$ or lower in Japanese can be taken as an indication of Malay heritage. Thus, the presence of types 15 and 16 of DYS385a, type 14 of DYS385b, type 9 of DYS391, type 10 of DYS392, type 18 of DYS456, type 16 of DYS437, type 10 of DYS533, type 15 of DYS576, types 23 and 25 of DYS635, type 10 of DYS439, and types 10 and 14 of GATA-H4 are types indicative of Malay identity. Similarly, we defined a type 
Table 2s Observed allele frequencies for DYS439 loci in Malay and Japanese

\begin{tabular}{ccc}
\hline \multirow{2}{*}{ Locus } & \multicolumn{2}{c}{ DYS439 } \\
\cline { 2 - 3 } & Malay & Japan \\
\hline Total Alleles & 218 & 426 \\
\hline Allele & \multicolumn{2}{c}{ Frequency } \\
\hline 9 & $0.0 \%$ & $0.2 \%$ \\
10 & $11.0 \%$ & $1.9 \%$ \\
11 & $39.0 \%$ & $17.4 \%$ \\
12 & $40.4 \%$ & $61.0 \%$ \\
13 & $7.8 \%$ & $15.5 \%$ \\
14 & $1.8 \%$ & $3.8 \%$ \\
15 & $0.0 \%$ & $0.2 \%$ \\
\hline p-Value & 0.000197448 \\
\hline MP & 0.334 & 0.428 \\
PD & 0.666 & 0.572 \\
PIC & 0.61 & 0.53 \\
\hline
\end{tabular}

Abbreviation: shown in Table 2a
Table 2t Observed allele frequencies for DYS389I loci in Malay and Japanese

\begin{tabular}{ccc}
\hline \hline \multirow{2}{*}{ Locus } & \multicolumn{2}{c}{ DYS389 I } \\
\cline { 2 - 3 } & Malay & Japan \\
\hline Total Alleles & 218 & 426 \\
\hline Allele & \multicolumn{2}{c}{ Frequency } \\
\hline 11 & $0.0 \%$ & $4.7 \%$ \\
12 & $35.3 \%$ & $14.8 \%$ \\
13 & $46.8 \%$ & $30.0 \%$ \\
14 & $17.4 \%$ & $48.8 \%$ \\
15 & $0.5 \%$ & $1.6 \%$ \\
\hline p-Value & $6.61623 \mathrm{E}-07$ \\
\hline MP & 0.374 & 0.353 \\
PD & 0.626 & 0.647 \\
PIC & 0.55 & 0.59 \\
\hline
\end{tabular}

Abbreviation: shown in Table 2a
Table $2 \mathrm{u}$ Observed allele frequencies for DYS389П loci in Malay and Japanese

\begin{tabular}{ccc}
\hline \hline \multirow{2}{*}{ Locus } & \multicolumn{2}{c}{ DYS389 II } \\
\cline { 2 - 3 } & Malay & Japan \\
\hline Total Alleles & 218 & 426 \\
\hline Allele & \multicolumn{2}{c}{ Frequency } \\
\hline 25 & $0.5 \%$ & $0.0 \%$ \\
27 & $2.3 \%$ & $6.8 \%$ \\
28 & $23.4 \%$ & $13.1 \%$ \\
29 & $34.9 \%$ & $26.3 \%$ \\
30 & $21.6 \%$ & $27.5 \%$ \\
31 & $11.9 \%$ & $22.5 \%$ \\
32 & $4.1 \%$ & $3.5 \%$ \\
33 & $1.4 \%$ & $0.0 \%$ \\
34 & $0.0 \%$ & $0.2 \%$ \\
\hline p-Value & \multicolumn{2}{c}{0.0654928} \\
\hline MP & 0.239 & 0.218 \\
PD & 0.761 & 0.782 \\
PIC & 0.72 & 0.75 \\
\hline
\end{tabular}

Abbreviation: shown in Table 2a with an allele frequency in Japanese 4-fold or higher than that in Malay. The presence of an allele that is known to have a frequency of $5 \%$ or lower in Malay can be taken as an indication of Japanese heritage. The presence of type 10 of DYS385a, type 10 of DYS549, type 13 of DYS643, types 21 and 28 of DYS481, type 21 of DYS576, and type 20 of DYS458 are types indicative of Japanese identity. Thus, the detailed allele distributions were compared between the two populations. There were several race-specific types that were present only in Malay or Japanese: type 12 of DYS19, types 7 and 11.1 of DYS643, type 19 of DYS481, type 9 of DYS533, type 21 of DYS390, type 33 of DYS389II, and type 13 of DYS458 were characteristic of Malay individuals; whereas types 8 and 14 of DYS643, types 13 and 14 of DYS438, type 22 of DYS570, and type 11 of DYS389I were characteristic of Japanese individuals. In a forensic context, the use of these race-specific types may permit distinction of persons of these two backgrounds.

No major difference was noted in polymorphisms between the two Mongoloid populations, but the allele frequency of 17 STRs did differ significantly. To distinguish Malay and Japanese, a dominant distribution zone was observed in each population based on the following 8 STRs: DYS385a, DYS389I, DYS438, DYS481, DYS390, DYS533, DYS439, and DYS643. In addition, by paying attention to types demonstrating the likelihood of a specific race (Malay-like type or Japanese-like type) and race-specific types, elements indicative of Malay or Japanese heritage were identified in 21 of the 23 STRs, excluding DYS393 and DYS448, suggesting the possibility of estimated identification in the two populations. These results are shown in Table 4 . 
Table 2v Observed allele frequencies for GATA-H4 loci in Malay and Japanese

\begin{tabular}{ccc}
\hline \multirow{2}{*}{ Locus } & \multicolumn{2}{c}{ GATA-H4 } \\
\cline { 2 - 3 } & Malay & Japan \\
\hline Total Alleles & 217 & 426 \\
\hline Allele & \multicolumn{2}{c}{ Frequency } \\
\hline 10 & $7.8 \%$ & $1.4 \%$ \\
11 & $36.9 \%$ & $50.5 \%$ \\
12 & $38.2 \%$ & $43.7 \%$ \\
13 & $14.3 \%$ & $4.0 \%$ \\
14 & $2.3 \%$ & $0.5 \%$ \\
15 & $0.5 \%$ & $0.0 \%$ \\
\hline p-Value & 0.00397189 \\
\hline MP & 0.309 & 0.447 \\
PD & 0.691 & 0.553 \\
PIC & 0.64 & 0.45 \\
\hline
\end{tabular}

Abbreviation: shown in Table 2a
Table 2w Observed allele frequencies for DYS458 loci in Malay and Japanese

\begin{tabular}{ccc}
\hline \multirow{2}{*}{ Locus } & \multicolumn{2}{c}{ DYS458 } \\
\cline { 2 - 3 } & Malay & Japan \\
\hline Total Alleles & 218 & 425 \\
\hline Allele & \multicolumn{2}{c}{ Frequency } \\
\hline 13 & $1.4 \%$ & $0.0 \%$ \\
14 & $6.4 \%$ & $2.4 \%$ \\
14.1 & $0.0 \%$ & $0.5 \%$ \\
15 & $15.6 \%$ & $26.8 \%$ \\
15.2 & $0.5 \%$ & $0.0 \%$ \\
16 & $28.4 \%$ & $15.3 \%$ \\
17 & $24.8 \%$ & $19.1 \%$ \\
18 & $16.5 \%$ & $18.4 \%$ \\
18.2 & $0.9 \%$ & $0.0 \%$ \\
19 & $4.6 \%$ & $11.5 \%$ \\
20 & $0.5 \%$ & $4.9 \%$ \\
20.2 & $0.5 \%$ & $0.0 \%$ \\
21 & $0.0 \%$ & $0.5 \%$ \\
23 & $0.0 \%$ & $0.7 \%$ \\
\hline p-Value & 0.0152059 \\
\hline MP & 0.200 & 0.182 \\
PD & 0.800 & 0.818 \\
PIC & 0.77 & 0.79 \\
\hline & & \\
\hline
\end{tabular}

Abbreviation: shown in Table 2a
Table 3 p-Values of 23 Y-STRs

\begin{tabular}{cc}
\hline \hline Locus & p-Value \\
\hline DYS549 & 0.2027570 \\
DYS570 & 0.1905520 \\
DYS437 & 0.1329590 \\
DYS19 & 0.0866405 \\
DYS389 II & 0.0654928 \\
DYS392 & 0.0571873 \\
DYS448 & 0.0188783 \\
DYS393 & 0.0178206 \\
DYS456 & 0.0172153 \\
DYS458 & 0.0152059 \\
DYS385b & 0.0052308 \\
GATA-H4 & 0.0039719 \\
DYS576 & 0.0022376 \\
DYS391 & 0.0021266 \\
DYS635 & 0.0017800 \\
DYS643 & 0.0009994 \\
DYS439 & 0.0001974 \\
DYS533 & 0.0001075 \\
DYS390 & 0.0000861 \\
DYS481 & 0.0000043 \\
DYS438 & 0.0000009 \\
DYS389 I & 0.0000007 \\
DYS385a & 0.0000006 \\
& \\
\hline
\end{tabular}

The results of this study suggest that the likelihood of Malay or Japanese genetic background can be judged based on Y-chromosome STR test results. As interchanges between the populations of Japan and Southeast Asian countries increase in the future, the ability to distinguish between Japanese and Malay individuals may become forensically important.

\section{References}

1) Hammer MF, Karafet TM, Park H, Omoto K,
Harihara S, Stoneking M, Horai S (2006) Dual origins of the Japanese: common ground for hunter-gatherer and farmer Y chromosomes. J Hum Genet 51:47-58.

2) Hanihara K (1991) Dual structure model for the population history of the Japanese. Japan Review 2:1-33.

3) Nakamura Y, Minaguchi K (2010) Sixteen X-chromosomal STRs in two octaplex PCRs in Japanese population and development of 15-locus multiplex PCR system. Int J Legal Med 124:405-414.

4) Nakamura Y, Samejima M, Minaguchi K (2016) Population genetics of identifiler system in Malaysia. Bull Tokyo Dent Coll 57: 233-239.

5) Raymond M, Rousset F (1995) GENEPOP (version 1.2): population genetics software for 
Table 4 Markers that may be useful in differentiating persons of Malay and Japanese heritage

\begin{tabular}{|c|c|c|c|c|c|c|}
\hline Y-STR & $\begin{array}{c}\text { Malay } \\
\text { dominant } \\
\text { zone }\end{array}$ & $\begin{array}{l}\text { Malay-like } \\
\text { type }\end{array}$ & $\begin{array}{l}\text { Malay-specific } \\
\text { type }\end{array}$ & $\begin{array}{l}\text { Japanese } \\
\text { dominant } \\
\text { zone }\end{array}$ & $\begin{array}{l}\text { Japanese- } \\
\text { like type }\end{array}$ & $\begin{array}{l}\text { Japanese- } \\
\text { specific type }\end{array}$ \\
\hline DYS19 & & & 12 & & & \\
\hline DYS 385a & 15 or higher & 15,16 & & 10 or lower & 10 & \\
\hline DYS 385b & & 14 & & & & \\
\hline DYS389 I & 12,13 & & & $\begin{array}{l}11 \text { or lower, } \\
14 \text { or higher }\end{array}$ & & 11 \\
\hline DYS389 II & & & 33 & & & \\
\hline DYS390 & & & 21 & & & \\
\hline DYS391 & & 9 & & & & \\
\hline DYS392 & & 10 & & & & \\
\hline DYS437 & & 16 & & & & \\
\hline DYS438 & 11 or lower & & & 13 or higher & & 13,14 \\
\hline DYS439 & 11 or lower & 10 & & 13 or higher & & \\
\hline DYS456 & & 18 & & & & \\
\hline DYS458 & & & 13 & & 20 & \\
\hline DYS481 & $22-25$ & & 19 & $\begin{array}{l}21 \text { or lower, } \\
26 \text { or higher }\end{array}$ & 21,28 & \\
\hline DYS533 & 10 or lower & 10 & 9 & 12 or higher & & \\
\hline DYS549 & & & & & 10 & \\
\hline DYS570 & & & & & & 22 \\
\hline DYS576 & & 15 & & & 21 & \\
\hline DYS635 & & 23,25 & & & & \\
\hline DYS643 & 11 or lower & & $7,11.1$ & 12 or higher & 13 & 8,14 \\
\hline GATA-H4 & & 10.14 & & & & \\
\hline
\end{tabular}

exact tests and ecumenicism. J Hered 86: 248-249.

6) Rebecca LC, Mark S, Allan CW (1987) Mitochondrial DNA and human evolution. Nature 325:31-36.

7) Sato Y, Shinka T, Ashraf AE, Yamauchi A, Iwamoto T, Nakahori Y (2014) Overview of genetic variation in the $\mathrm{Y}$ chromosome of modern Japanese males. Anthropological Science 122:131-136.

8) Tereba A (1995) Tools for analysis of population statistics. Profiles DNA 2:14-16.

9) Thompson JM, Ewing MM, Frank WE, Pogemiller IJ, Nolde CA, Koehler DJ, Shaffer AM, Rabbach DR, Fulmer PM, Sprecher CJ, Storts DR (2013) Developmental validation of the PowerPlex ${ }^{\circledR}$ Y23 System: A single multiplex Y-STR analysis system for casework and database samples. Forensic Sci Int Genet 7: 240-250.
10) Underhill PA, Shen P, Lin AA, Jin L, Passarino G, Yang WH, Kauffman E, Bonné-Tamir B, Bertranpetit J, Francalacci P, Ibrahim M, Jenkins T, Kidd JR, Mehdi SQ, Seielstad MT, Wells RS, Piazza A, Davis RW, Feldman MW, Cavalli-Sforza LL, Oefner PJ (2000) Y chromosome sequence variation and the history of human populations. Nature Genetics 26: 358-361.

\section{Correspondence:}

Dr. Yasutaka Nakamura Department of Forensic Odontology and Forensic Anthropology, Tokyo Dental College, 2-9-18 Kanda-Misakicho, Chiyoda-ku, Tokyo 101-0061, Japan E-mail: ynakamura@tdc.ac.jp 